\title{
Sustainability of Groundwater Supplies in the Northern Atlantic Coastal Plain Aquifer System
}

Groundwater is the Nation's principal reserve of freshwater. It provides about half our drinking water, is essential to food production, and facilitates business and industry in developing economic well-being. Groundwater is also an important source of water for sustaining the ecosystem health of rivers, wetlands, and estuaries throughout the country. The decreases in groundwater levels and other effects of pumping that result from largescale development of groundwater resources have led to concerns about the future availability of groundwater to meet all our Nation's needs. Assessments of groundwater availability provide the science and information needed by the public and decision makers to manage water resources and use them responsibly (Alley and others, 2013).

The U.S. Geological Survey (USGS) is conducting largescale multidisciplinary regional studies of groundwater availability as part of its ongoing assessments of the principal aquifers of the Nation (Reilly and others, 2008). These regional studies are intended to provide citizens, communities, and natural resource managers with knowledge of the status of the Nation's groundwater resources and how changes in land use, water use, and climate have affected and are likely to affect those resources now and in the future (Dennehy and others, 2015).

\section{Northern Atlantic Coastal Plain Aquifer System}

The Northern Atlantic Coastal Plain (NACP) aquifer system extends from Long Island in New York to northeastern North Carolina and includes aquifers primarily within New York, New Jersey, Delaware, Maryland, Virginia, and North Carolina (fig. 1). This aquifer system is made up of 10 regional aquifers and 9 interlayered confining units that form a seaward-dipping wedge of unconsolidated to partially consolidated sediments that are typically thousands of feet thick along the coastline, with a maximum thickness of about 10,000 feet near the edge of the Continental Shelf.

The NACP aquifer system is one of the smallest of the 66 principal aquifer systems in the Nation, and yet it ranks 7 th in population served and 13th overall in total groundwater withdrawals (Reilly and others, 2008). Increases in population and changes in land use during the past 100 years have resulted in diverse increased demands for freshwater, with groundwater serving as a vital source of drinking water for the nearly 20 million people who live in the region. Groundwater withdrawals in 2013 were estimated to be about 1,300 million gallons per day (Mgal/d) and account for about 40 percent of the drinking water supply for the area of the NACP aquifer system. Densely populated areas tend to have high rates of withdrawals and, therefore, are most susceptible to the effects of these withdrawals over

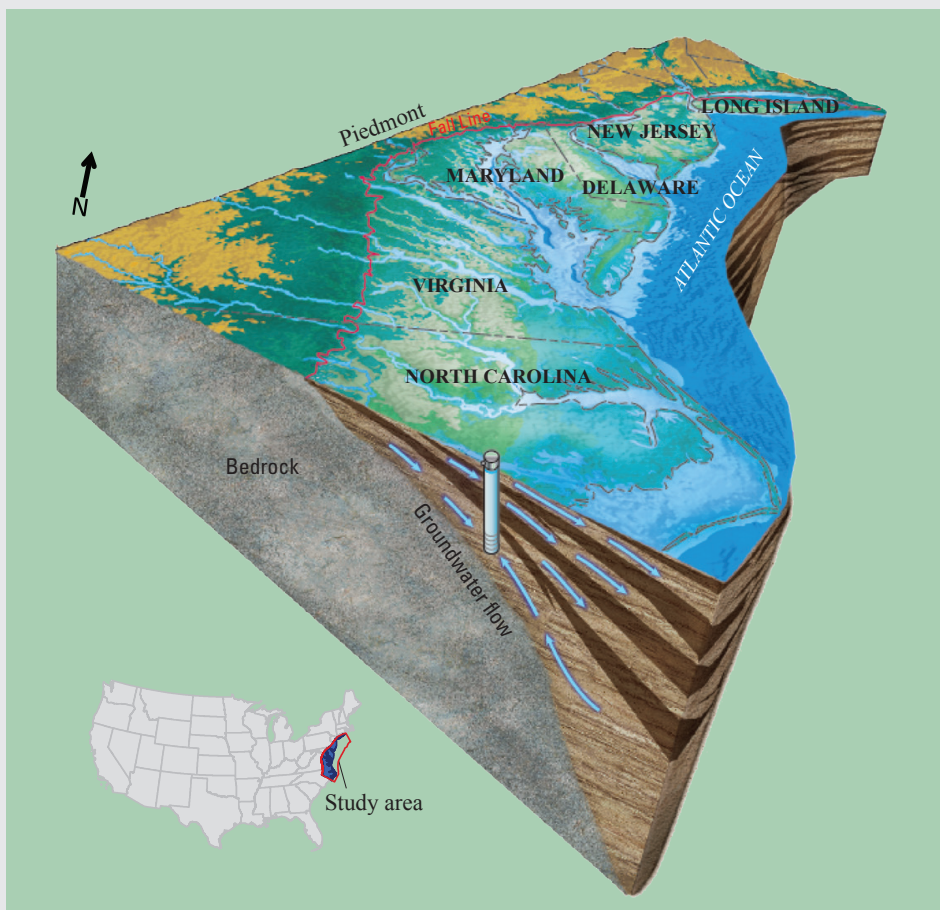

Figure 1. Block diagram showing the Northern Atlantic Coastal Plain aquifer system, which includes the areas east of the Fall Line from Long Island to northern North Carolina. This multilayer system consists of confined aquifers and confining units capped by an unconfined, surficial aquifer. Groundwater flows predominantly from west to east from the Fall Line to the Atlantic Ocean, except where high-capacity pumping wells alter this regional flow pattern.

time. Water level decreases in some aquifers are more than 100 feet from levels before 1900 (Masterson and others, 2016a). Regional hydrological effects also extend across State lines and under large embayments, making the State-level management of competing local domestic, industrial, agricultural, and environmental demands for water increasingly more problematic.

\section{Hydrologic Budget}

A hydrologic budget quantitatively accounts for inflows, outflows, and changes in storage of a hydrologic system. Analyses of hydrologic budgets are necessary to understanding the sources of water for a groundwater system such the NACP aquifer system and how groundwater withdrawals affect the components of the hydrologic budget. In the end, the amount of water entering a groundwater system plus the amount being removed from storage must balance the amount of water leaving the system (Reilly and others, 2008). 
Hydrologic budgets were calculated with a groundwater model developed for the NACP aquifer system (Masterson and others, 2016a,b) to quantify how much water enters and leaves this aquifer system (fig. 2). From 2005 to 2008, water entered the aquifer system at a rate of $18,070 \mathrm{Mgal} / \mathrm{d}$ as recharge and flows through the shallow, unconfined aquifer and discharged either to streams or directly to coastal waters without reaching the deep, confined aquifers. An additional source of recharge to the aquifer system was the return of about $230 \mathrm{Mgal} / \mathrm{d}$ of wastewater from domestic septic systems.

Groundwater pumping in the confined part of the aquifer system (below the fine-grained confining units) can cause a reduction in water pressure, which can result in water lost or released from storage. This release of water from storage is considered an additional inflow into the aquifer system because

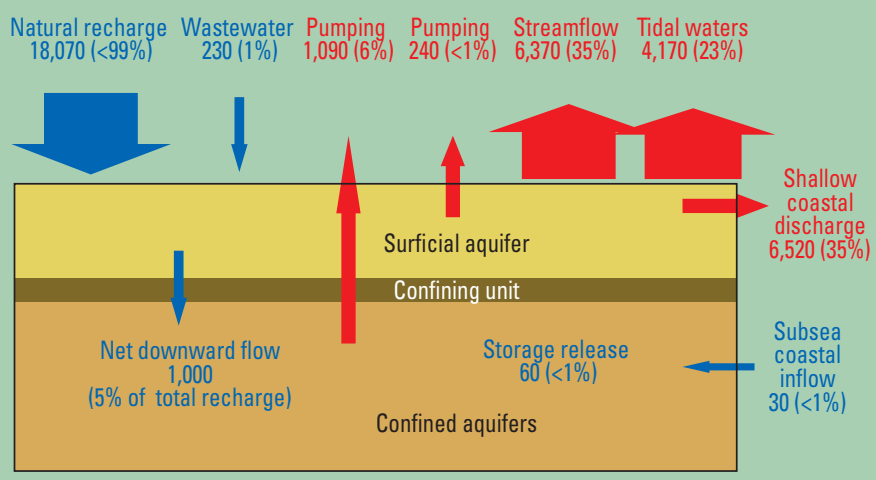

Figure 2. Flow diagram showing the hydrologic budget for the Northern Atlantic Coastal Plain aquifer system. From 2005 to 2008, about 18,300 million gallons per day of water entered and left this multilayered aquifer system. Modified from Masterson and others (2016a). Values are in million gallons per day; percentages (\%) are of total recharge. $<$, less than.

it contributes to the hydrologic budget as an inflow component to balance groundwater withdrawals. From 2005 to 2008, water was released from storage at a rate of about $60 \mathrm{Mgal} / \mathrm{d}$ (fig. 2).

Discharge to streams and the coast and groundwater withdrawals make up the outflows that balance the inflows in the NACP aquifer system. From 2005 to 2008, 93 percent of the total outflow from the aquifer system was to surface waters, with 58 percent of total outflow discharging directly to coastal areas and 35 percent discharging to streams. The remaining 7 percent of the total outflow from the aquifer system was accounted for by withdrawals of groundwater from pumping wells.

In addition to understanding how inflows and outflows currently are balanced for the entire aquifer system, it is also important to understand how only the confined part of the aquifer system is responding to groundwater withdrawals because that is where most of the pumping occurs in the NACP area. About 92 percent of groundwater withdrawals from the confined aquifers are replaced by the increase in downward flow of water from the surficial aquifer. The remaining 8 percent of the groundwater removed by pumping is balanced by water released from storage ( 5 percent) and the inflow of saline groundwater (3 percent) from subsea coastal areas into the freshwater part of the aquifer system (fig. 2).
The response of the aquifer system to groundwater withdrawals can happen slowly and change over time; therefore, a hydrologic budget was developed to quantify how the NACP aquifer system has responded to groundwater withdrawals since large-scale pumping began in 1900 (fig. 3). The hydrologic budget presented in figure 3 illustrates how the NACP aquifer system has responded to 27.8 trillion gallons (Tgal) of groundwater being removed by pumping from 1900 to 2013. This response to pumping includes changes in four hydrologic budget components - reduction in the amount of groundwater discharge to streams, reduction in the amount of groundwater discharge to the coast, increased release (or depletion) of groundwater from storage, and increased wastewater return flow. About 72 percent of the water pumped from the aquifer system from 1900 to 2013 was groundwater that otherwise would have discharged to streams and the coast. Over that period, this reduction in groundwater discharge to the coast was about 57 percent of the total water pumped from the NACP aquifer system. About 20 percent of the water pumped from the aquifer system was returned into the system as recharge from wastewater through septic systems (the wastewater return flow component). The remaining 8 percent of the water removed by pumping was water released from storage (groundwater storage depletion).

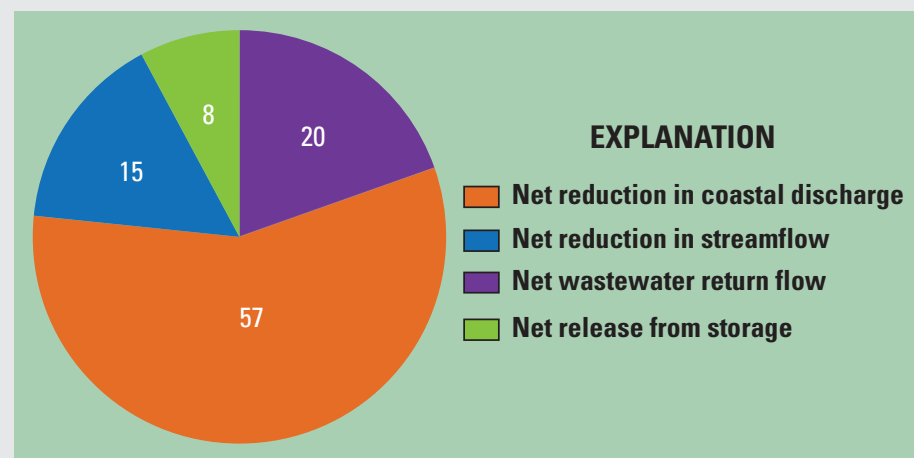

Figure 3. Pie chart showing cumulative change in hydrologic budget components (as percentages) in response to groundwater pumping for the entire Northern Atlantic Coastal Plain aquifer system from 1900 to 2013. Most of the 27.8 trillion gallons of water removed from the aquifer system by pumping was as a reduction in the amount of groundwater that otherwise would have discharged to the coast ( 57 percent) and streams (15 percent).

On a regional scale, hydrogeologic conditions and the resulting response to groundwater pumping can vary substantially in both time and space. For example, about 11.3 Tgal of water was removed from the local aquifer system on Long Island from 1900 to 2013, most of which (77 percent) was groundwater that otherwise would have discharged to the coast; only about 5 percent was from groundwater that otherwise would have discharged to streams, and 4 percent was from groundwater released from storage. About 14 percent of the total groundwater withdrawn from the aquifer system was returned as recharge of wastewater by septic systems (fig. $4 A$ ). In contrast, about 2.4 Tgal of water was removed from the local aquifer system in Virginia during the same 113-year period, but only about 15 percent was from groundwater that otherwise would have discharged to streams ( 9 percent) and to the coast ( 6 percent; fig. $4 C$ ). Most (about 85 percent) of the response to pumping in 
the local aquifer system in Virginia was balanced by the return of wastewater as recharge to the surficial aquifer (36 percent), groundwater storage depletion (24 percent), and from inflow of groundwater from neighboring States (25 percent; fig. 4C).

\section{Hydrogeologic Controls on Groundwater Flow}

Unconfined aquifers in the NACP aquifer system are in direct hydrologic connection with surface water features and receive inflow directly from recharge from precipitation. Confined aquifers are physically separated from the unconfined (or surficial) aquifer by overlying confining units (figs. 2 and 5) and are not in direct hydrologic connection with surface water

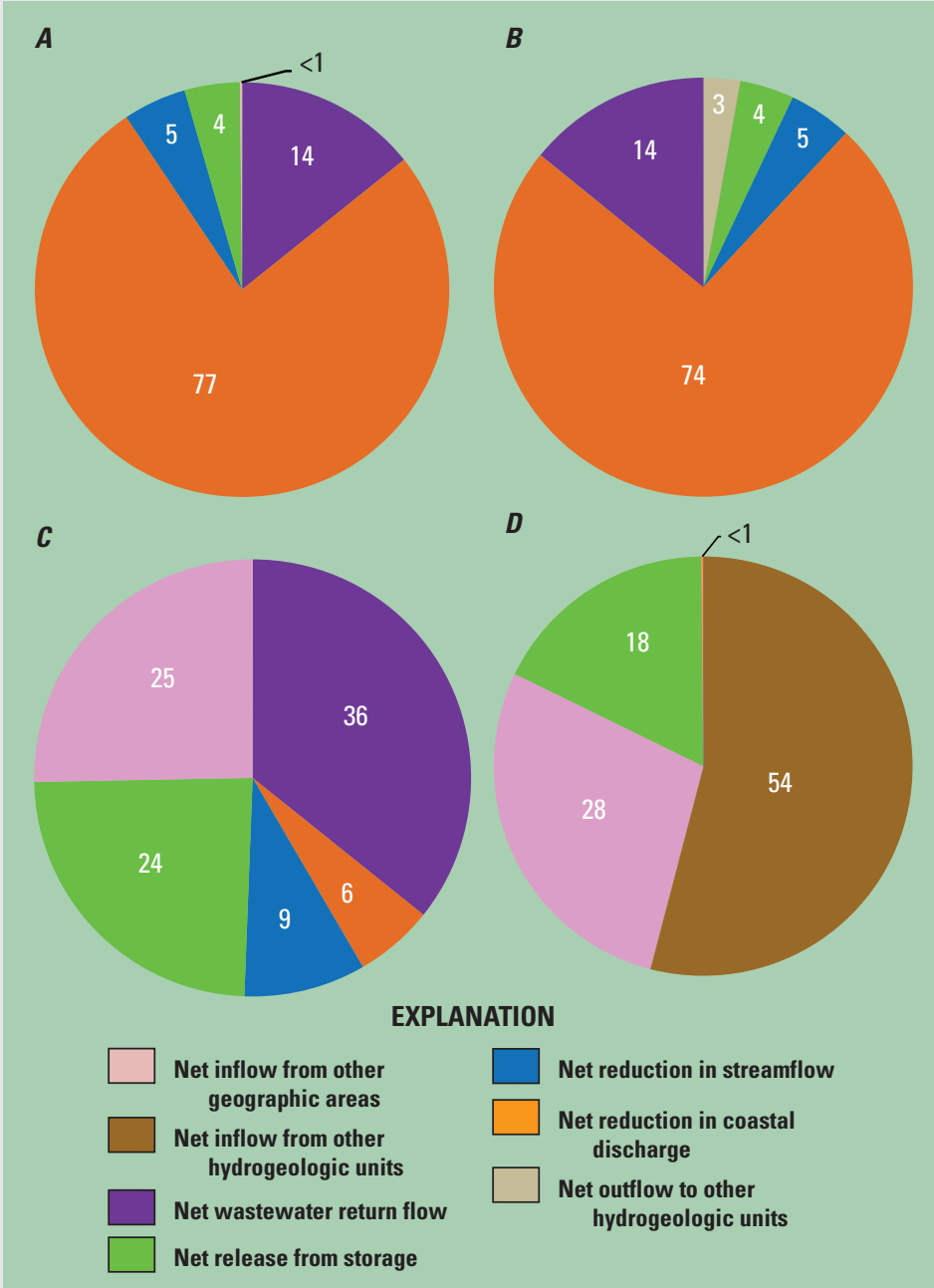

Figure 4. Pie charts showing cumulative response of the hydrologic budget components (as percentages) to groundwater withdrawals from 1900 to 2013 in $A$, the Long Island aquifer system, $B$, unconfined aquifers of the Long Island aquifer system, $C$, the Virginia aquifer system, and $D$, the confined Potomac aquifer of the Virginia aquifer system. The difference between the Virginia aquifer system and the confined Potomac aquifer occurs because, whereas water withdrawn by pumping from the unconfined aquifers on Long Island directly interacts with the surface waters, water withdrawn by pumping in the confined Potomac aquifer induces downward flow from overlying hydrogeologic units; the water in the overlying hydrogeologic units includes groundwater that otherwise would have discharged to surface waters and increased inflow from wastewater return flow. features, thus, only receive water from the downward flow of water through overlying hydrogeologic units.

Differences in the hydrogeology on Long Island and in Virginia are the reason these local aquifer systems respond differently to groundwater pumping. Almost all (98 percent) withdrawals on Long Island in 2013 were from the surficial aquifer

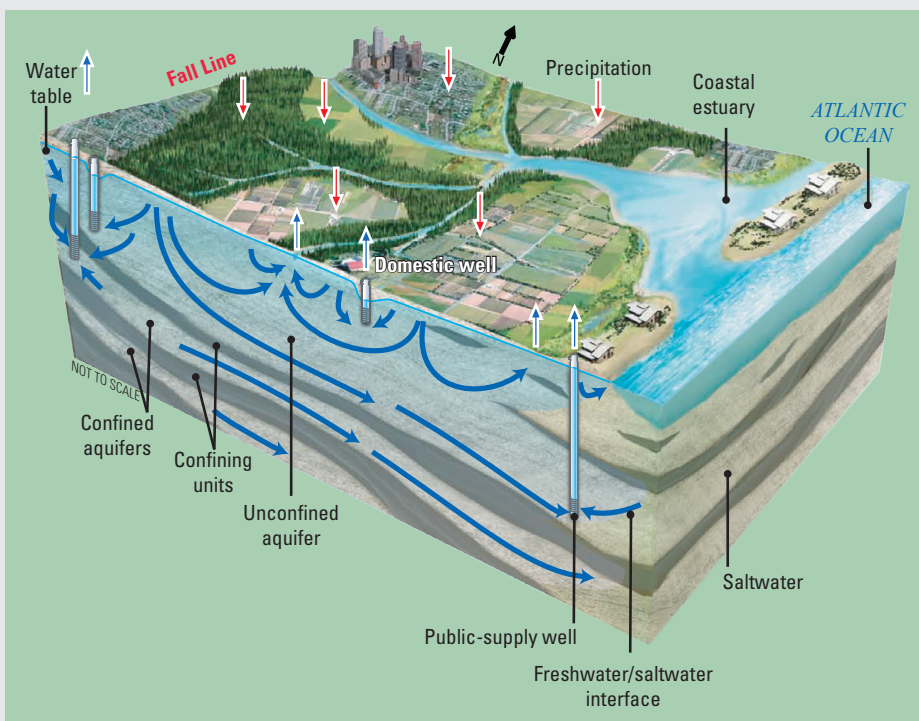

Figure 5. Block diagram showing conceptual model of the flow system with the Northern Atlantic Coastal Plain aquifer system. The diagram illustrates how water enters the flow system as streamflow across the Fall Line and as recharge from precipitation; this water then leaves the flow system as groundwater is withdrawn by pumping wells or discharges to streams and to the coast. Red arrows indicate inflow from recharge and wastewater return flow, and blue arrows indicate outflow from groundwater discharge to streams and to the coast as well as water removed from private and public-supply wells. Modified from DeSimone and others (2014).

(known locally as the upper glacial aquifer) and the underlying Magothy aquifer; both aquifers are essentially unconfined and, therefore, in direct hydrologic connection with surface water features (fig. 6A). Conversely, about 87 percent of withdrawals in Virginia in 2013 were from the Potomac-Patapsco aquifer (known locally as the Potomac aquifer), which is a confined aquifer separated from the surficial aquifer by multiple aquifers and confining units (fig. 6B).

Groundwater withdrawals from the unconfined aquifers on Long Island, from 1900 to 2013, were offset primarily by a reduction in the amount of groundwater that otherwise would have discharged to the coast (74 percent) and to streams (5 percent; fig. $4 B$ ). Increase in inflow from wastewater return flow was about 14 percent of the total 11.3 Tgal of groundwater pumped from these aquifers, and release of groundwater from storage (groundwater depletion) accounted for about 4 percent. The remaining 3 percent of change in groundwater flow from pumping on Long Island was the downward flow of water through the Raritan confining unit from pumping in the underlying Lloyd aquifer (fig. 6A). The response of the unconfined aquifers on Long Island (fig. $4 B$ ) is very similar to the total response of the Long Island aquifer system (fig. $4 A$ ) in that most (about 79 percent) of the response to pumping from these aquifers was as a reduction in the amount of groundwater that otherwise would have discharged to surface waters. 


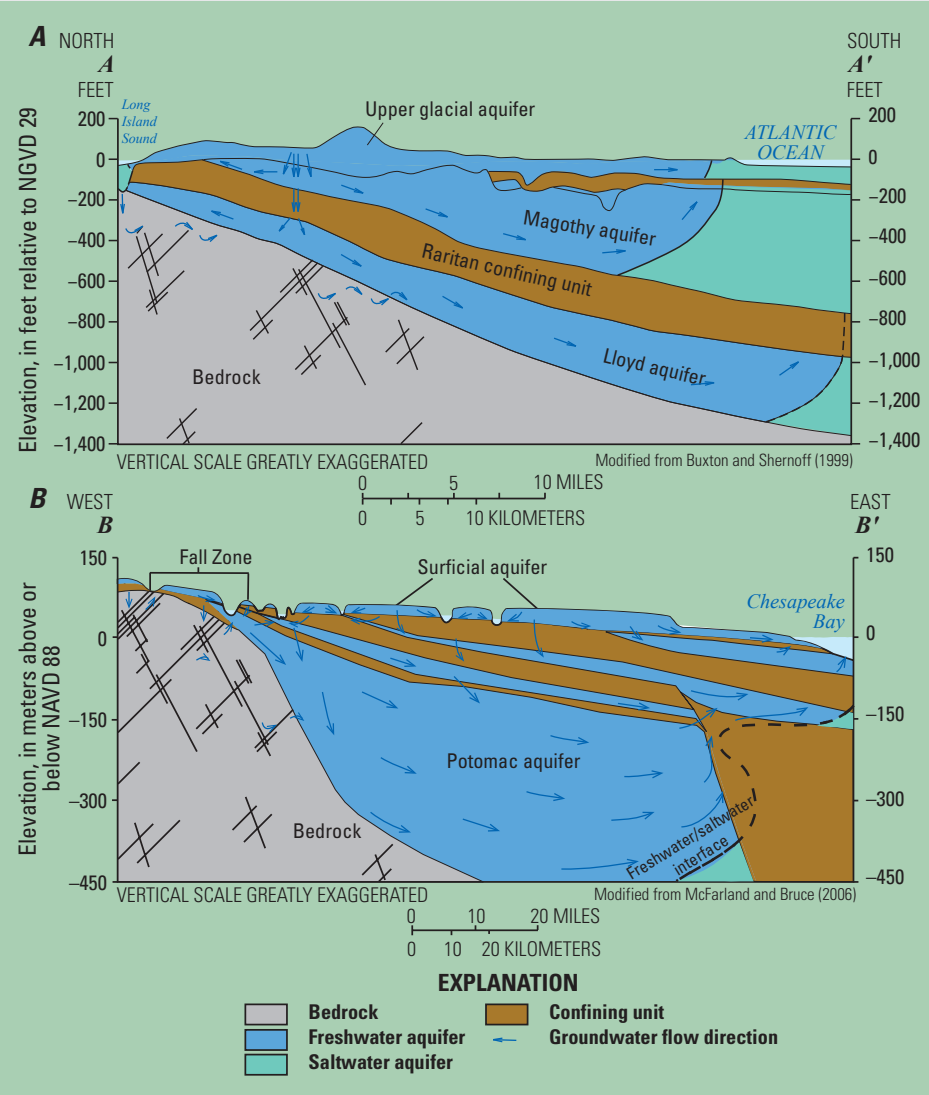

Figure 6. Cross sections of hydrogeology for the geographic areas of $A$, Long Island, New York, and $B$, Virginia. About 98 percent of the total groundwater withdrawals (pumping) on Long Island are from the Magothy and upper glacial aquifers, which are essentially unconfined aquifers. In Virginia, about 87 percent of the total groundwater withdrawals are from the Potomac aquifer, which is separated from the surficial aquifer by intervening confined aquifers and confining units. The lines of the sections are shown in figure 7. NGVD 29, National Geodetic Vertical Datum of 1929; NAVD 88, North American Vertical Datum of 1988.

Even though 87 percent of all withdrawals in Virginia are from the Potomac aquifer (fig. $6 B$ ), the response of the Potomac aquifer (fig. $4 D$ ) differs substantially from the response of the entire Virginia aquifer system (fig. $4 C$ ). The main differences are that about half ( 51 percent) of the response of the entire Virginia aquifer system from pumping is from increased inflow of wastewater (36 percent), from neighboring States (other geographic areas; 25 percent), and from reductions in the amount of groundwater that otherwise would have discharged to surface waters (15 percent), whereas in the Potomac aquifer, about 54 percent of the response to pumping is from the downward flow of water from overlying hydrogeologic units. These differences indicate that pumping from the Potomac aquifer does not directly affect groundwater discharge to streams and coastal waters and is not receiving recharge directly from the return of wastewater at land surface. Instead, pumping from the Potomac aquifer is inducing downward flow from the overlying hydrogeologic units, and it is that downward flow that indirectly causes reductions in the amount of groundwater discharge to streams and to the coast. In addition, the return of wastewater as recharge to the surficial aquifer does not directly contribute water to the confined Potomac aquifer, but may offset some of the hydrologic effects of pumping in the Potomac aquifer on the surficial aquifer.
The unconfined aquifers of Long Island and the confined aquifer in Virginia also differ in the source of the water pumped from wells. On Long Island, water pumped from wells comes from captured groundwater that otherwise would have discharged to streams or coastal waters (fig. $4 B$ ), whereas nearly all of the water pumped from wells in the confined Potomac aquifer comes from the induced downward flow of water from the overlying hydrologic units, from the inflow of water from neighboring States, and from the release of water from storage (fig. 4D). Ultimately, the induced downward flow of water from the overlying hydrologic units will result in a decrease in outflow to surface waters in Virginia, but the response time for that is much slower than that on Long Island and may not be fully resolved for many years to come.

\section{Groundwater Storage Depletion}

Groundwater storage depletion can be defined as a reduction in the volume of groundwater that is stored in the subsurface; this depletion can have negative effects on water supply and can lead to land subsidence, reductions in surface water flows and spring discharges, and loss of wetlands (Konikow, 2013). Only about 8 percent of the total amount of groundwater stored in the entire NACP aquifer system from 1900 to 2013 was depleted by pumping (fig. 3); however, depletion varied substantially from Long Island to North Carolina (fig. 7). Pumping on Long Island and in New Jersey accounted for about 68 percent of all withdrawals in the NACP aquifer system, but accounted for only about 35 percent of the total depletion of groundwater storage from 1900 to 2013. Conversely, pumping in Virginia and northern North Carolina, accounted for 14 percent of water withdrawn from the NACP aquifer system, yet almost half (46 percent) of the total groundwater storage depletion in the entire NACP aquifer system occurred in this area.

The differences in groundwater storage depletion throughout the NACP aquifer system (fig. 7) can be explained by the hydrogeologic conditions of the primary aquifers used for water supply. In the northern part of the study area, most of the groundwater withdrawals are from the shallow, unconfined part of the aquifer system and most of the aquifer system response to pumping is from captured groundwater that otherwise would have discharged to surface waters, resulting in only small amounts of pumped water leading to groundwater storage depletion. In the southern part of the study area, most of the withdrawals are from the deep, confined portion of the aquifer system, and reductions in the amount groundwater that otherwise would have discharged to surface waters is a small amount of the total response to pumping, leading to the release of water from storage (groundwater storage depletion) being an important source of water to pumping wells.

\section{Implications for Sustainability}

Groundwater sustainability can be defined as the development and use of groundwater in a manner that can be maintained for indefinite time without causing unacceptable environmental or socioeconomic consequences (Alley and others, 1999). The primary concern of groundwater sustainability in the NACP aquifer system is balancing the increasing demands for a potable water supply with the quantity, timing, and quality of groundwater flow and storage required to sustain freshwater 


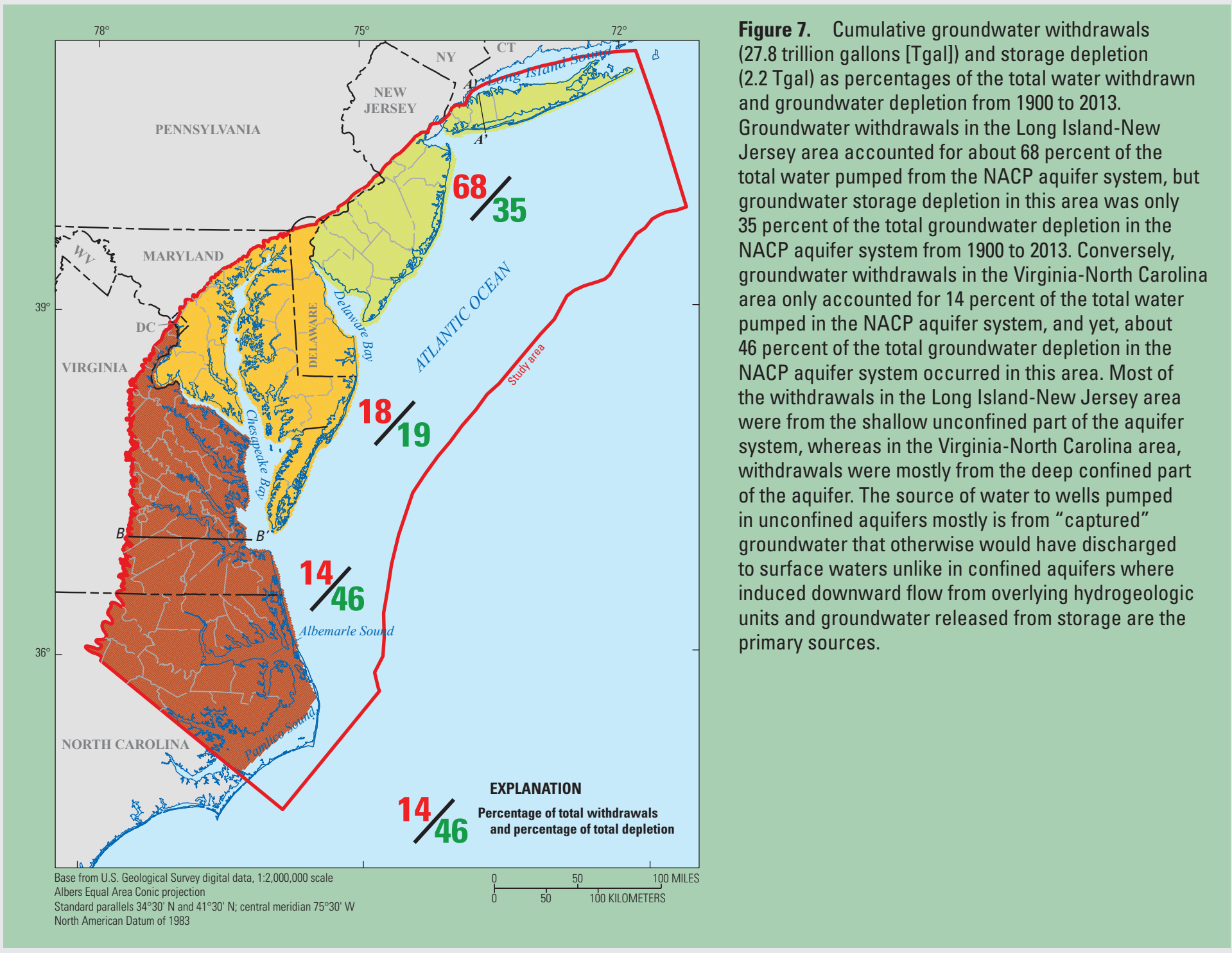

and estuarine ecosystems, such as the New York-New Jersey harbor estuary, Barnegat Bay in New Jersey, the meadowlands in Hackensack, N.J., the inland bays and seashore of Delaware, the Delaware River Estuary, and the Chesapeake Bay (http://www.chesapeakebay.net/), the largest estuary in the United States and the first in the Nation to be selected for restoration as an integrated watershed ecosystem.

Assessing sustainability in the thick, multilayered NACP aquifer system can be complicated because the effects of groundwater pumping can differ throughout the system, depending on if groundwater is being withdrawn from the shallow, unconfined aquifers or the deep, confined aquifers. In the shallow aquifers such as on Long Island, the hydrologic response to pumping can be much quicker than in the deep aquifers in Virginia where the effects tend to manifest themselves slowly over time and the full effects of pumping from these deep confined aquifers may not be evident for many years after pumping began. Therefore, in unconfined aquifers (either the surficial aquifer or in aquifers in direct hydrologic connection with the surficial aquifer), which are the primary water-supply source in locations such as the Long Island-New Jersey area (fig. 7), groundwater storage depletion is of less concern than in confined aquifers because the unconfined aquifer system is able to reach a new hydraulic equilibrium more quickly and with fewer unresolved long-term effects.
Although groundwater storage depletion from unconfined aquifers may be of lesser concern than from confined aquifers, concerns exist that groundwater pumped from these unconfined aquifers potentially could be more susceptible to agricultural, industrial, or urban land-use activities (fig. 5), which could adversely affect water quality in these areas. Furthermore, groundwater withdrawals from these unconfined aquifers have the potential to reduce groundwater discharge to receiving waters on the surface such as rivers and coastal waters that depend on groundwater to sustain freshwater and estuarine ecosystems and the livelihoods that depend on them.

Conversely, in parts of the NACP aquifer system such as in Virginia and North Carolina (fig. 7) where the majority of groundwater pumping is from the confined aquifers, the primary source of water to these aquifers is downward flow from overlying hydrogeologic units (fig. $4 D$ ) rather than directly from recharge from precipitation at the water table (fig. 5). Groundwater withdrawals from these confined aquifers may be less susceptible in the short term to adverse land-use activities than those from unconfined aquifers and less likely to cause hydrologic effects on groundwater-dependent surface waters; however, because these confined aquifers are not replenished directly by recharge at the water table, groundwater withdrawals in the long term may outpace replenishment, resulting in overuse of this resource. 
Additionally, groundwater storage depletion from the confining units that separate the confined aquifers from the surficial aquifer is of particular concern because water removed from the clayey sediments in confining units, unlike from the sandy sediments that make up the confined aquifers, cannot be replenished as these units gradually compress. This nonrecoverable loss of water from storage can result in land subsidence. Moreover, where these confining units are thick and the amount of water released from storage is relatively large, rising sea levels at low land surface elevations, such as in the lower part of the Chesapeake Bay, could result in increased flooding and surface inundation (Eggleston and Pope, 2013).

Another concern in coastal aquifer systems such as the NACP aquifer system is saltwater intrusion from overpumping of groundwater near the coast. This concern is one that affects both unconfined and confined aquifers and results from pumping that captures groundwater that otherwise would discharge to the coast. Once the balance between freshwater and saltwater is altered, the interface between freshwater and saltwater begins to move landward, and pumping wells near this hydrologic boundary are at increased risk of saltwater intrusion (figs. 2 and 5). Masterson and others (2016a) assessed the potential for saltwater intrusion in the NACP aquifer system and determined that the potential for regional-scale effects are small for conditions in 2013 but may be of local concern in parts of Long Island, New Jersey, and Virginia where high-capacity pumping wells are in close proximity to the interface between freshwater and saltwater.

Informed management of the NACP aquifer system can help ensure a regionally sustainable groundwater resource. Long-term monitoring and assessment of water quality and environmental conditions and of the potential for overexploitation of this groundwater resource can assist decision makers in the management of this vital resource. Groundwater models such as that detailed in Masterson and others (2016b) serve as tools to advance the understanding of the responses of the various components of hydrologic budgets for the entire NACP aquifer system and for each of the subregional systems within the study area. Models also can be used to forecast future system response to development at a scale relevant to regional water management decisions and to examine the NACP aquifer system at different spatial and temporal scales to better understand how changing hydrologic stresses across the aquifer system can influence the sustainability of groundwater resources in the area.

\section{By John P. Masterson and Jason P. Pope}

\section{For more information, contact}

Water Availability and Use Science Program

U.S. Geological Survey

150 National Center

12201 Sunrise Valley Drive

Reston, VA 20192

http://water.usgs.gov/wausp/

\section{References Cited}

Alley, W.M., Evenson, E.J., Barber, N.L., Bruce, B.W., Dennehy, K.F., Freeman, M.C., Freeman, W.O., Fischer, J.M., Hughes, W.B., Kennen, J.G., Kiang, J.E., Maloney, K.O., Musgrove, MaryLynn, Ralston, Barbara, Tessler, Steven, and Verdin, J.P., 2013, Progress toward establishing a national assessment of water availability and use: U.S. Geological Survey Circular 1384, 34 p. [Also available at http://pubs.usgs.gov/circ/1384/.]

Alley, W.M., Reilly, T.E., and Franke, O.L., 1999, Sustainability of ground-water resources: U.S. Geological Survey Circular 1186, 79 p. [Also available at https://pubs.er.usgs.gov/publication/ cir1186.]

Buxton, H.T., and Shernoff, P.K., 1999, Ground-water resources of Kings and Queens Counties, Long Island, New York: U.S. Geological Survey Water-Supply Paper 2498, 113 p., 7 pls., accessed March 11, 2013, at https://pubs.er.usgs.gov/publication/wsp2498.

Dennehy, K.F., Reilly, T.E., and Cunningham, W.L., 2015, Groundwater availability in the United States-The value of quantitative regional assessments: Hydrogeology Journal, v. 23, no. 8, p. 1629-1632. [Also available at http://dx.doi.org/10.1007/ s10040-015-1307-5.]

DeSimone, L.A., McMahon, P.B., and Rosen, M.R., 2014, The quality of our Nation's waters - Water quality in principal aquifers of the United States, 1991-2010: U.S. Geological Survey Circular 1360, 151 p. [Also available at http://dx.doi.org/10.3133/cir1360.]

Eggleston, Jack, and Pope, Jason, 2013, Land subsidence and relative sea-level rise in the southern Chesapeake Bay region: U.S. Geological Survey Circular 1392, 30 p. [Also available at https://pubs.er.usgs.gov/publication/cir1392.]

Konikow, L.F., 2013, Groundwater depletion in the United States (1900-2008): U.S. Geological Survey Scientific Investigations Report 2013-5079, 63 p., accessed June 23, 2013, at https://pubs.er.usgs.gov/publication/sir20135079.

Masterson, J.P., Pope, J.P., Fienen, M.N., Monti, Jack, Jr., Nardi, M.R., and Finkelstein, J.S., 2016a, Assessment of groundwater availability in the Northern Atlantic Coastal Plain aquifer system from Long Island, New York, to North Carolina: U.S. Geological Survey Professional Paper 1829, 76 p. [Also available at http://dx.doi.org/10.3133/pp1829.]

Masterson, J.P., Pope, J.P., Fienen, M.N., Monti, Jack, Jr., Nardi, M.R., and Finkelstein, J.S., 2016b, Documentation of a groundwater flow model developed to assess groundwater availability in the Northern Atlantic Coastal Plain aquifer system from Long Island, New York, to North Carolina: U.S. Geological Survey Scientific Investigations Report 2016-5076, 70 p. [Also available at http://dx.doi.org/10.3133/sir20165076.]

McFarland, E.R., and Bruce, T.S., 2006, The Virginia Coastal Plain hydrogeologic framework: U.S. Geological Survey Professional Paper 1731, 118 p., 25 pls., accessed March 11, 2013, at https://pubs.er.usgs.gov/publication/pp1731/.

Reilly, T.E., Dennehy, K.F., Alley, W.M., and Cunningham, W.L., 2008, Ground-water availability in the United States: U.S. Geological Survey Circular 1323, 70 p. [Also available at http://pubs.usgs.gov/circ/1323/.] 